\title{
Enterovirus infection in human pancreatic islet cells, islet tropism in vivo and receptor involvement in cultured islet beta cells
}

\author{
P. Ylipaasto ${ }^{1}$ K. Klingel ${ }^{2}$ A. M. Lindberg ${ }^{3}$ T. Otonkoski ${ }^{4}$ R. Kandolf K $^{2}$ T. Hovi ${ }^{1}$ M. Roivainen $^{1}$ \\ ${ }^{1}$ Enterovirus Laboratory, National Public Health Institute, Helsinki, Finland \\ 2 Department of Molecular Pathology, University Hospital Tübingen, Tübingen, Germany \\ ${ }^{3}$ Department of Chemistry and Biomedical Sciences, University of Kalmar, Kalmar, Sweden \\ ${ }^{4}$ Hospital for Children and Adolescents and Program of Developmental and Reproductive Biology, Biomedicum, \\ University of Helsinki, Helsinki, Finland
}

\section{Abstract}

Aims/hypothesis. It is thought that enterovirus infections cause beta-cell damage and contribute to the development of Type 1 diabetes by replicating in the pancreatic islets. We sought evidence for this through autopsy studies and by investigating known enterovirus receptors in cultured human islets.

Methods. Autopsy pancreases from 12 newborn infants who died of fulminant coxsackievirus infections and from 65 Type 1 diabetic patients were studied for presence of enteroviral ribonucleic acid by in situ hybridisation. Forty non-diabetic control pancreases were included in the study. The expression and role of receptor candidates in cultured human islets were investigated with receptor-specific antibodies using immunocytochemistry and functional assays.

Results. Enterovirus-positive islet cells were found in some of both autopsy specimen collections, but not in control pancreases. No infected cells were seen in exocrine tissue. The cell surface molecules, poliovirus re- ceptor and integrin $\alpha v \beta_{3}$, which act as enterovirus receptors in established cell lines, were expressed in beta cells. Antibodies to poliovirus receptor, human coxsackievirus and adenovirus receptor and integrin $\alpha v \beta_{3}$ protected islets and beta cells from adverse effects of poliovirus, coxsackie B viruses, and several of the arginine-glycine-aspartic acid motifs containing enteroviruses and human parechovirus 1 respectively. No evidence was found for expression of the decay-accelerating factor which acts as a receptor for several isletcell-replicating echoviruses in established cell lines.

Conclusions/interpretation. The results show a definite islet-cell tropism of enteroviruses in the human pancreas. Some enteroviruses seem to use previously identified cell surface molecules as receptors in beta cells, whereas the identity of receptors used by other enteroviruses remains unknown. [Diabetologia (2004) 47:225-239]

Keywords Enterovirus - Coxsackievirus - Echovirus · Poliovirus · Human pancreas · Islets · Beta cells ·

Receptors
Received: 4 July 2003 / Revised: 6 October 2003

Published online: 15 January 2004

(C) Springer-Verlag 2004

M. Roivainen (-)

Enterovirus Laboratory, National Public Health Institute, Mannerheimintie 166, 00300 Helsinki, Finland

E-mail: merja.roivainen@ktl.fi

Abbreviations: A-549, Human lung carcinoma cell line . CAV, coxsackie A virus - CBV, coxsackie B virus; DAF, decay-accelerating factor - EV, echovirus - HBSS, Hanks' balanced salt solution - FITC, fluorescein isothiocyanate . GMK, a green monkey kidney cell line - HCAR, human coxsackievirus and adenovirus receptor - HPEV-1, human parechovirus $1 \cdot \mathrm{PV}-1$, poliovirus type $1 \cdot \mathrm{PVR}$, poliovirus receptor $\cdot$ RGD, arginine-glycine-aspartic acid

RNA, ribonucleic acid

P. Ylipaasto and K. Klingel contributed equally to the study
Type 1 diabetes is characterised by destruction of the beta cells in pancreatic islets. The process, which finally leads to complete beta-cell loss and onset of clinical disease, starts years before any clinical symptoms and is thought to result from several factors involving host genes, autoimmune responses and cytokines, as well as environmental factors. Results from previous cross-sectional and prospective studies on patients with Type 1 diabetes and/or prediabetic individuals have suggested that enterovirus infections are involved in the development of the disease $[1,2$, $3,4,5,6,7,8,9,10,11,12,13,14,15]$.

The Enterovirus genus of the Picornaviridae family is a large group of human pathogens traditionally divided into polioviruses, coxsackieviruses, echoviruses (EV) and the new enteroviruses. Recently, enteroviruses have been reclassified as poliovirus and human enterovirus $\mathrm{A}$ to $\mathrm{D}$ on the basis of molecular homology [16]. 
The first step in viral infection is the attachment of the virus to its receptor, a cell surface molecule which viruses have adapted to gain entry into the cell. Receptors are also considered to be key determinants in tissue tropism of viruses. To date several cell surface receptors are known for enteroviruses, among them members of the integrin and immunoglobulin superfamilies normally involved in cell adhesion. Three serotypes of poliovirus use poliovirus receptor (PVR), a member of the immunoglobulin superfamily [17] and members of human enterovirus $\mathrm{C}$ use intercellular adhesion molecule-1 [18]. Integrin $\alpha v \beta 3$, also known as the vitronectin receptor, works as a receptor for coxsackievirus A 9 (CAV-9) [19] and other arginineglycine-aspartic acid motifs (RGD) containing enteroviruses $[20,21]$, whereas another integrin, $\alpha 2 \beta 1$, works as a receptor for EV-1 [22, 23]. In addition, a complement regulatory protein, i.e. decay-accelerating factor (DAF), and a protein called human coxsackievirus and adenovirus receptor (HCAR) are used for cellular entry by coxsackieviruses and several EVs [24, $25,26,27,28]$. However, the function of these receptors in viral entry is not understood in detail and it is possible that additional host factors are needed for complete entry. The situation is further complicated by the fact that some viruses use more than one cellular receptor [18, 29, 30, 31, 32], sometimes even in one cell line $[33,34]$. The current knowledge of receptor usage is mostly based on studies using continuous cell lines common in laboratories. Little if anything is known about enterovirus receptors of primary human cells and tissues.

Enterovirus serotypes associated with Type 1 diabetes have been tentatively identified in several ways $[1,35]$. Assuming that infection of pancreatic beta cells is relevant to enterovirus-induced damage, we have studied patterns and consequences of enterovirus infections in human beta cells isolated from the organs of deceased persons. According to previous results, human beta cells are highly susceptible to enterovirus infection [36, 37, 38, 39, 40]. The effect of virus replication on beta-cell survival and function was, however, dependent on serotype and/or strain, ranging from rapid cytolysis with simultaneous severe functional damage of surviving cells to subtle morphological changes only [38]. These observations are of interest as there are very few published data on enterovirus infections in human pancreata in vivo. Moreover, in most experimental models of murine coxsackie B virus (CBV) infection, the exocrine pancreas is destroyed and the islets often remain intact $[41,42,43$, $44,45,46,47]$.

For this study we had access to two sets of autopsy materials suitable for assessing potential islet tropism of enterovirus infections in vivo. This enabled us to study in situ hybridisation in pancreata from newborn infants who died of fulminant coxsackievirus infections, as well as in pancreata from deceased adoles- cent and adult Type 1 diabetic patients. In another line of studies, we examined the background for this tropism and studied the presence and function of the selected enterovirus receptors in cultured primary human islets.

\section{Subjects and methods}

Autopsy pancreases. Autopsy pancreases from 12 newborn infants who died of fulminant coxsackievirus infections at the age of 3 days to 10 months [48] were studied for presence of enteroviral ribonucleic acid (RNA) by in situ hybridisation. Most of these patients had coxsackievirus myocarditis and six out of seven enterovirus-positive pancreases showed evidence of insulitis. We also studied 65 autopsy pancreases from adolescent and adult Type 1 diabetic patients. The age span of the Type 1 diabetic patients was 18 to 52 years, the ratio of men to women was $2: 3$ and the duration of diabetes ranged from a few weeks up to 19 years. The enterovirus status of the patients was not known but their autopsy hearts were negative for coxsackievirus myocarditis. In addition, 40 non-diabetic pancreases from subjects matched for age and sex were included in the study as controls. Autopsy specimens obtained from [48] and the University of Tübingen were treated as anonymous tissue, and studies carried out in accordance with the Declaration of Helsinki of the World Medical Assembly. According to the statement of the ethics committee of the University of Tübingen this kind of historic study can be done without specific permissions.

In situ hybridisation for detection of enteroviral RNA. Formalin-fixed, paraffin-embedded pancreatic tissue was obtained from newborn infants who died of fulminant coxsackievirus infection [48] and from autopsies of patients suffering from Type 1 diabetes. Control tissue included normal pancreases from newborn infants and adults and pancreas from patients with chronic pancreatitis. Enteroviral plus-strand RNA in pancreatic tissue was detected using single-stranded ${ }^{35} \mathrm{~S}$-labelled RNA probes, which were synthesised from the dual-promoter plasmid pCVB3-R1 by using SP6 RNA polymerase [49]. Control RNA probes were obtained from non-recombinant transcription vector pSPT18 (Amersham Pharmacia Biotec, Piscataway, N.J., USA). Pre-treatment, hybridisation, and washing of de-waxed paraffin tissue sections ( $6 \mu$ m thick) were carried out as described previously. Briefly, tissue sections were incubated for $18 \mathrm{~h}$ at $42^{\circ} \mathrm{C}$ in hybridisation buffer containing ${ }^{35} \mathrm{~S}$-labelled strand-specific CVB3 RNA probes (500 ng/ml) in $10 \mathrm{mmol} / \mathrm{l}$ Tris- $\mathrm{HCl}, \mathrm{pH} \mathrm{7.4,50 \%} \mathrm{(volume} \mathrm{by} \mathrm{volume)} \mathrm{deionised} \mathrm{form-}$ amide, $600 \mathrm{mmol} / 1 \mathrm{NaCl}, 1 \mathrm{mmol} / \mathrm{l}$ EDTA with $0.02 \%$ polyvinylpyrrolidone, $0.02 \%$ dithiothreitol, denatured sonicated salmon sperm DNA at $200 \mu \mathrm{g} / \mathrm{ml}$, and rabbit liver transfer RNA (Boehringer Mannheim, Mannheim, Germany) at $100 \mu \mathrm{g} / \mathrm{ml}$. Washing steps, including digestion for $30 \mathrm{~min}$ at $37^{\circ} \mathrm{C}$ of non-hybridised single-stranded RNA probes by RNase A $(20 \mu \mathrm{g} / \mathrm{ml})$ (Boehringer Mannheim) in $10 \mathrm{mmol} / \mathrm{l}$ Tris- $\mathrm{HCl}$, $\mathrm{pH} 8.0,0.5 \mathrm{~mol} / \mathrm{l} \mathrm{NaCl}$, were done as described previously [49]. Slide preparations were subjected to autoradiography (NTB2 film, Kodak, Rochester, N.Y., USA), exposed for 3 weeks at $4^{\circ} \mathrm{C}$ and counterstained with haematoxylin-eosin.

Human beta cells. Human pancreatic islets were isolated and purified either in Brussels, Belgium, at the Central Unit of the $\beta$-Cell Transplant or in Uppsala, Sweden, at Uppsala University Hospital. They were then sent to Helsinki, Finland, as freefloating islets after 1-15 days of culture in Ham's F10 medium 
supplemented with $10 \mathrm{mmol} / \mathrm{l}$ HEPES, $\mathrm{pH} 7.35$, and $2 \%$ calf serum. Before experiments, the suspended islets were maintained in sterile non-adherent culture plates in serum-free medium (Ham's F10 medium containing 2 mmol/l HEPES, pH 7.4, 1\% BSA, penicillin and streptomycin).

Viruses. Laboratory strains of CBV (CBV-2/Ohio-1, 4/J.V.B, 5/Faulkner), EV (6/D'Amori) and 9 (Hill and Barty), CAV-9 (CAV-9/Griggs), human parechovirus 1 (HPEV-1/Harris, previously known as echovirus 22) and poliovirus type 1 (PV-1/Sabin) were obtained either from the American Type Culture Collection (Manassas, Va., USA) or from the World Health Organization Enterovirus Reference Laboratory (Copenhagen, Denmark). Viruses were passaged in continuous cell lines of monkey kidney origin (GMK) or human lung carcinomas (A549) (American Type Culture Collection).

A clinical strain isolated from a diabetic patient was included in the study. The EV 9 DM strain was isolated from a stool sample of a 6-week-old baby suffering from acute Type 1 diabetes. The strain was isolated in tertiary monkey kidney cells [50] and passaged twice in primary monkey kidney cells before experiments.

The serotype of all virus preparations used was confirmed by a neutralisation assay with type-specific antisera.

Enterovirus receptor-specific antibodies. Polyclonal antibodies to PVR (NAETZ8) and integrin $\alpha v \beta 3$ were produced in-house by immunising rabbits with three to four doses of purified proteins together with Freund's complete (the first dose) or incomplete adjuvant (with boosters). The highly purified form of integrin $\alpha v \beta 3$ from human placenta was purchased from Chemicon (cat no. CC1021, Temecula, Calif., USA), and purified soluble His-tagged fusion protein of PVR was provided by E. Wimmer from the Department of Molecular Genetics and Microbiology, State University of New York, New York, USA. Monoclonal antibodies to DAF [51] used in immunostaining were provided by T. Kinoshita, Department of Immunoregulation, Research Institute of Microbial Diseases, Osaka University, Japan. The monoclonal antibody against HCAR, RmcB [52] was kindly provided by L. Philipson, Karolinska Institute, Stockholm, Sweden.

Replication of viruses. Free-floating islets pretreated with Hanks' balanced salt solution (HBSS) supplemented with $20 \mathrm{mmol} / \mathrm{l} \mathrm{HEPES}$, pH 7.4, h-HBSS, penicillin and streptomycin or receptor-specific antibodies (30-60 min at room temperature) were infected with apparent high multiplicity of infection (30 to 100) by different virus preparations in the absence or presence of the same receptor antibodies (anti-HCAR, 1:50; anti-PVR and anti- $\alpha v \beta 3,1: 50$ to $1: 300)$. After adsorption for $1 \mathrm{~h}$ at $36^{\circ} \mathrm{C}$, the inoculum virus was removed and the cells were washed twice with h-HBSS. Then serum-free incubation medium (Ham's F10 medium plus 1\% BSA, $25 \mathrm{mmol} / \mathrm{l}$ HEPES, $\mathrm{pH} 7.4$, penicillin and streptomycin), supplemented or not with the receptor antibodies (dilution 1:50 to 1:300), was added to all cultures including uninfected controls. Infected and uninfected islets were divided into aliquots on 96-well non-tissue culture plates (for virus titration, immunofluorescence and viability stainings) or 24-well non-tissue culture plates (for perifusion, insulin and DNA), and incubated at $36^{\circ} \mathrm{C}$. During the experiment, the incubation medium was changed at two- or three-day intervals.

For virus titration, samples of suspended islets harvested at 0,1 and 2 days after infection were frozen and thawed three times to release the virus, clarified by low-speed centrifugation, and assayed for total infectivity using end-point dilutions in microwell cultures of GMK cells (HPEV-1 in A-549 cells).
Cytopathic effects were assessed by microscopy after one week and tissue culture infectious dose titres were calculated as described earlier [37].

Immunocytochemistry of infected islets. Samples of infected and uninfected islets were harvested one day after infection on glass slides using a cytocentrifuge, and fixed with cold methanol for $15 \mathrm{~min}$ at $-20^{\circ} \mathrm{C}$. After washing (three times with $\mathrm{PBS})$, they were double-stained for $1 \mathrm{~h}$ at $36^{\circ} \mathrm{C}$ with enterovirus-specific polyclonal rabbit antiserum (1:400; KTL-910, ref. [53]) and insulin-specific polyclonal sheep antiserum (1:200; The Binding Site, Birmingham, England). Visualisation was achieved using fluorescein isothiocyanate (FITC) and Red-X conjugated anti-species sera (711-095-152 and 713-295-147 respectively; Jackson ImmunoResearch Laboratory, West Grove, Pa. USA), and analysed using a confocal microscope (Leica TCS NT, Wetzlar, Germany).

Immunocytochemistry of cell surface expression of enterovirus receptors. Expression of enterovirus receptors on primary human islets was carried out by staining samples of live unfixed islets with receptor-specific antibodies (polyclonal antibodies, dilution 1:500 for $30 \mathrm{~min}$ at $22^{\circ} \mathrm{C}$; monoclonal antibodies, dilution $10 \mu \mathrm{g} / \mathrm{ml}$ for $2 \mathrm{~h}$ at $4^{\circ} \mathrm{C}$ ). After staining with polyclonal receptor antibodies, the islets were fixed and made impermeable with cold methanol $\left(15 \mathrm{~min}\right.$ at $\left.-20^{\circ} \mathrm{C}\right)$, and stained for $1 \mathrm{~h}$ at $36^{\circ} \mathrm{C}$ with insulin-specific antibody $(1: 200$; The Binding Site), followed by a 30-min incubation with FITC and Red Xlabelled-anti-species conjugate (Jackson ImmunoResearch). The anti-DAF staining was followed by a 30-min incubation with Red X-conjugated anti-mouse antibody (Jackson ImmunoResearch) and then fixed with cold methanol. The samples were analysed using a confocal microscope.

Co-localisation of enterovirus receptors with virus particles. Samples of live islets were infected with an apparently high multiplicity of PV-1 or coxsackievirus A9. After 60 min incubation at 16 to $18^{\circ} \mathrm{C}$ the infected islets were stained with antireceptor antibodies (anti-PVR or anti- $\alpha \mathrm{v} \beta 3$, dilution 1:500) and enterovirus group-specific anti-peptide antibody (produced in house by immunising sheep four times with the immunodominant highly conservative VP1-derived peptide; dilution 1:600). Visualisation was achieved by FITC- and Red X- labelled anti-species conjugates (Jackson ImmunoResearch). Before analysis the islets were cytocentrifuged (Thermo Shandon, Runcorn, UK) on glass slides and fixed with cold methanol $\left(15 \mathrm{~min}\right.$ at $\left.-20^{\circ} \mathrm{C}\right)$.

DNA and insulin content of cells. For the measurement of cellular DNA and insulin content, islet cells were homogenised ultrasonically in distilled water. DNA was measured from dried samples fluorometrically based on diaminobenzoic acidinduced fluorescence [54]. Insulin was measured with a commercial solid-phase insulin RIA kit (DPC, Los Angeles, Calif., USA) after overnight extraction with acid ethanol [55].

Cell viability. The viability of islet cells after infection was measured using a commercial kit (the live/dead-cell assay, L3224, Molecular Probes, Leiden, The Netherlands). According to the manufacturer's instructions for staining, islets harvested at different time points were incubated with the labelling solution for $30 \mathrm{~min}$ at RT in the dark, and analysed with a confocal microscope (Leica).

Beta-cell function. Insulin secretion in response to glucose and glucose plus theophylline was studied by perifusion as described previously [37, 56]. Briefly, after taking samples for 

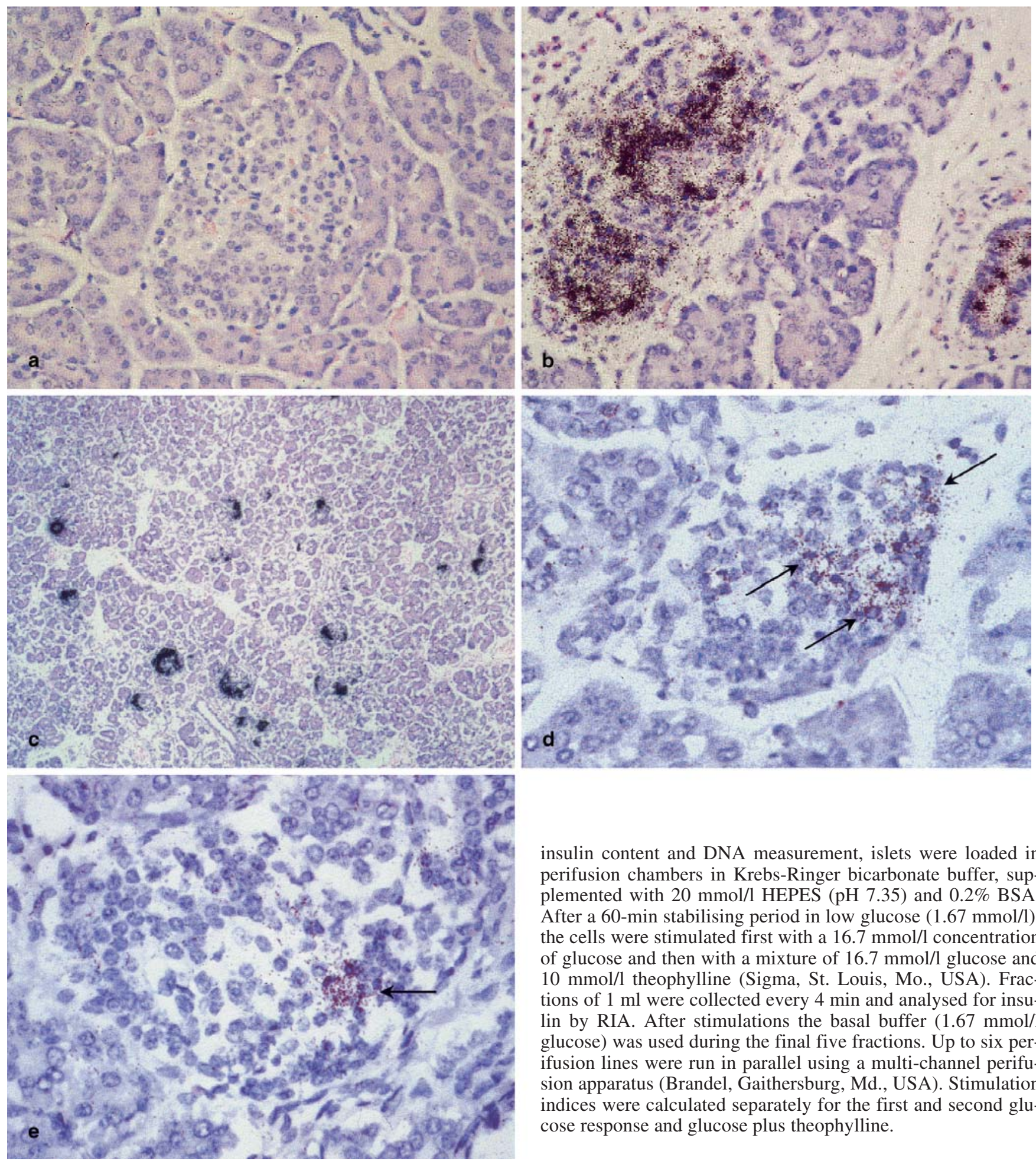

Fig. 1a-e. Islet-cell tropism of enteroviruses in human pancreas. Human pancreases obtained by autopsies were analysed for enteroviral RNA by in situ hybridisation. The first three panels show pancreas from one uninfected control baby (a) and from two newborn infants who died of coxsackievirus infections (b, c). Viral RNA (black silver grains) was found in several islets and some pancreatic duct cells but not in exocrine tissue. Other panels $(\mathbf{d}, \mathbf{e})$ show pancreases from two Type 1 diabetic patients. Note the black silver grains in the islets, reflecting cells which contain virus RNA

insulin content and DNA measurement, islets were loaded in perifusion chambers in Krebs-Ringer bicarbonate buffer, supplemented with $20 \mathrm{mmol} / \mathrm{l}$ HEPES ( $\mathrm{pH} \mathrm{7.35)}$ ) and 0.2\% BSA. After a 60 -min stabilising period in low glucose $(1.67 \mathrm{mmol} / \mathrm{l})$, the cells were stimulated first with a $16.7 \mathrm{mmol} / \mathrm{l}$ concentration of glucose and then with a mixture of $16.7 \mathrm{mmol} / \mathrm{l}$ glucose and $10 \mathrm{mmol} / \mathrm{l}$ theophylline (Sigma, St. Louis, Mo., USA). Fractions of $1 \mathrm{ml}$ were collected every $4 \mathrm{~min}$ and analysed for insulin by RIA. After stimulations the basal buffer $(1.67 \mathrm{mmol} / \mathrm{l}$ glucose) was used during the final five fractions. Up to six perifusion lines were run in parallel using a multi-channel perifusion apparatus (Brandel, Gaithersburg, Md., USA). Stimulation indices were calculated separately for the first and second glucose response and glucose plus theophylline.

\section{Results}

Compartments of human pancreas infected by enteroviruses in vivo. In our in situ hybridisation studies on 12 pancreases from autopsies of coxsackievirus-infected children, 7 out of the 12 pancreases were positive for enteroviral RNA, which was found in numerous pancreatic islets and in some duct cells but not in exocrine tissue (Fig. 1b,c). 
a

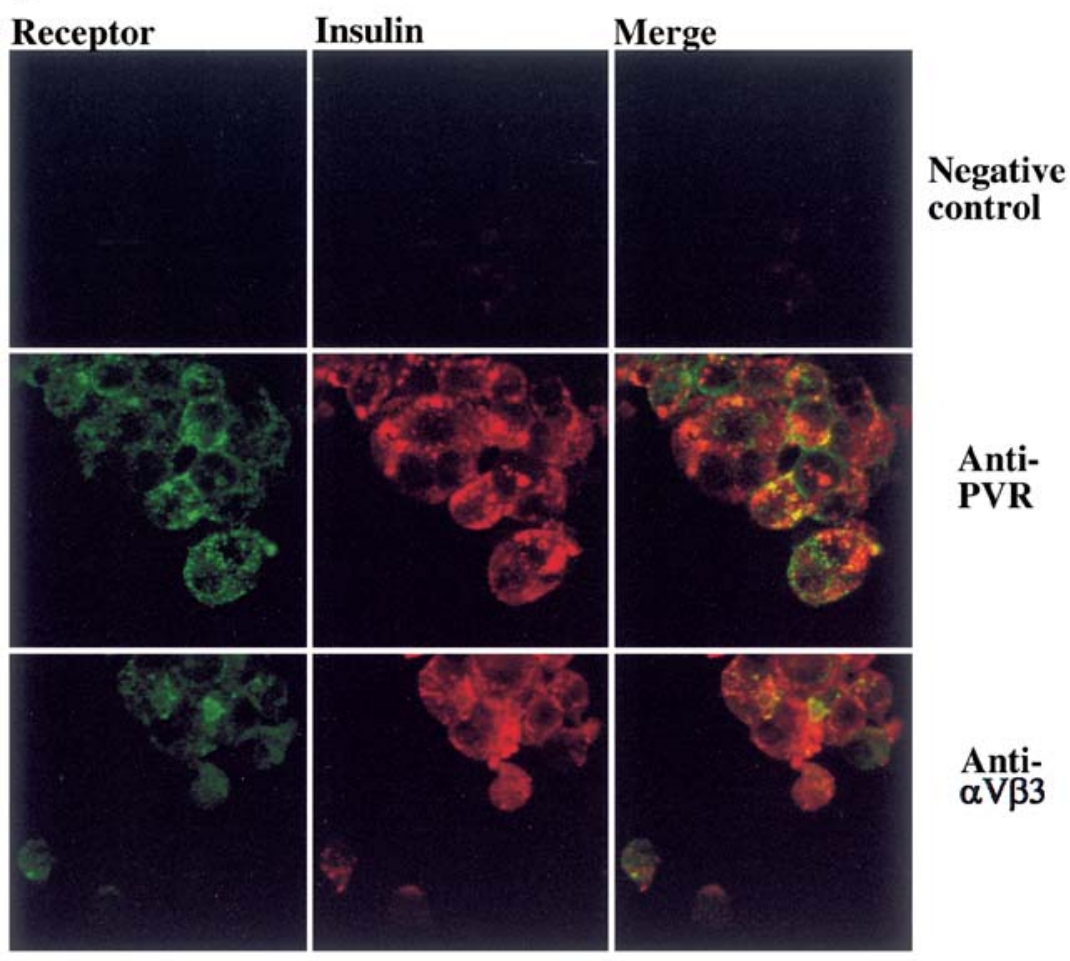

b

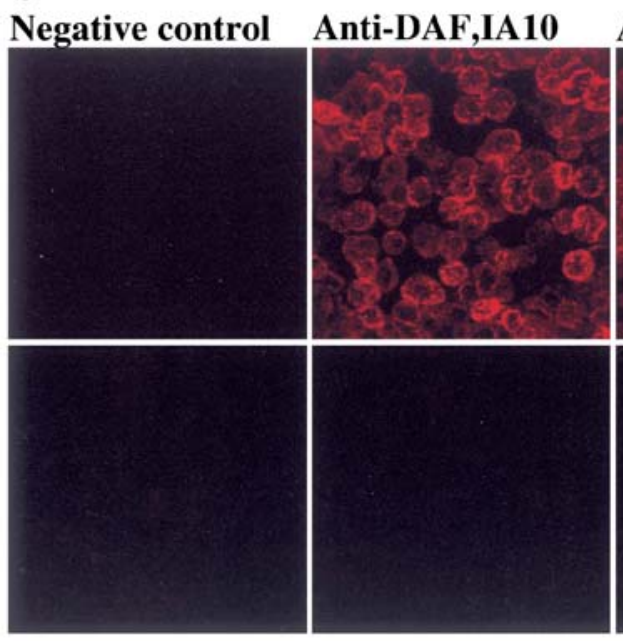

Anti-DAF,VIIIA7

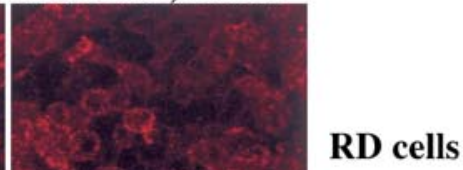

Fig. 2a, b. Expression of enterovirus receptors in beta cells Samples of cultured islets (a) were stained with polyclonal anti-receptor antibodies, dilution 1:500 (poliovirus receptor PVR; integrin $\alpha v \beta 3$ ). Reactions were made visible with fluorescein isothiocyanate-conjugated anti-rabbit conjugate. After receptor staining the islets were fixed with methanol and stained with insulin-specific antibody followed by Red X-labelled anti-sheep conjugate. Colour codes: green, receptor; red, insulin; yellow-orange, receptors in beta cells. Samples of cultured islets and human rhabdomyosarcoma cells (b) were stained with two different monoclonal antibodies to decay-accelerating factor (dilution: $10 \mu \mathrm{g} / \mathrm{ml}$ ). Visualisation was achieved by Red X-labelled anti-mouse conjugate

Insulitis was evident in six out of seven enterovirus-positive pancreases, showing that the morphological characteristic of insulitis matched well with the presence of viral RNA. Uninfected neonatal control pancreases were negative, as shown in one newborn infant (Fig. 1a). When pancreases from Type 1 diabetic patients (18-52 years of age) were studied for enteroviral RNA using the same in situ hybridisation technique, positive results were obtained in 4 out of 65 patients. In all four of these diabetic pancreases the enterovirus-positive cells were detected exclusively in islets, as shown in two patients (Fig. 1d,e). In contrast, pancreatic control tissues from 40 nondiabetic patients were consistently negative for enteroviral RNA. 


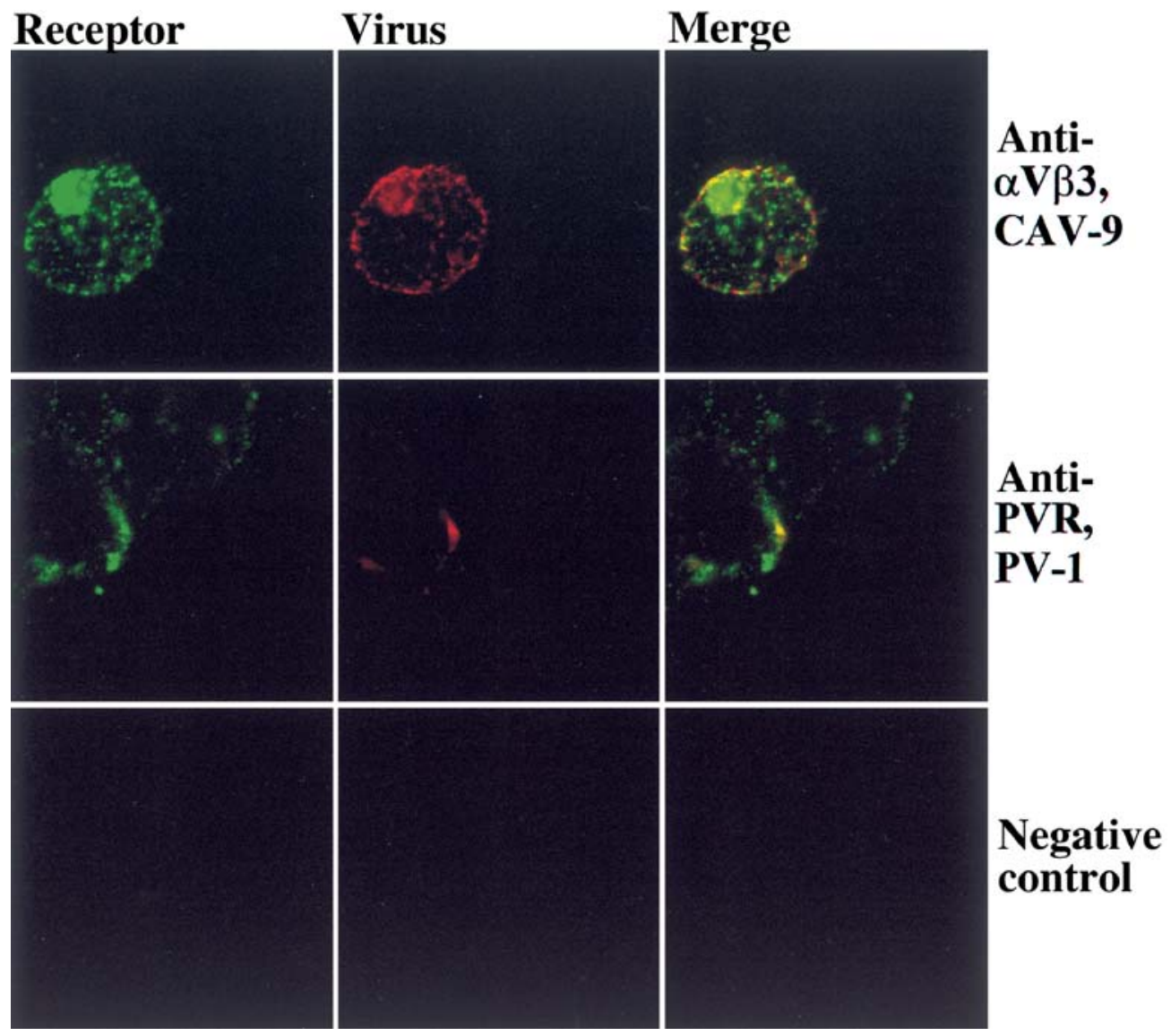

Fig. 3. Co-localisation of enterovirus receptors with virus particles in human islet cells. Samples of live islets were infected, with apparent high multiplicity, with poliovirus type 1 (PV-1) or coxsackievirus A9 (CAV-9). After $60 \mathrm{~min}$ incubation at $16-18^{\circ} \mathrm{C}$ the infected islets were stained with anti-receptor antibody (anti-poliovirus receptor PVR or anti- $\alpha v \beta 3$, dilution $1: 500)$ and virus-recognising polyclonal antibody (1:600, produced in a sheep). Visualisation was achieved by fluorescein isothiocyanate- and Red X-labelled anti-species conjugates (green: receptor; red: virus; yellow-orange: co-localisation). At the end of the assay the islets were cytocentrifuged on glass slides and fixed with cold methanol

Expression of different enterovirus receptors in primary human islets. Cell surface expression of PVR and integrin $\alpha v \beta 3$, both known to act as enterovirus receptors in established cell lines, was clearly evident (Fig. 2a). Double immunofluorescence staining for insulin and virus receptors verified expression of these cell surface molecules in beta cells (Fig. 2a). In contrast, islets stained with monoclonal antibodies to DAF were completely negative (Fig. 2b). As a positive control for DAF, cells from human rhabdomyosarcoma cell line were stained simultaneously using the same preparations of DAF-monoclonal antibodies, and a strong cell surface expression of DAF was seen in these cells when stained with two different antibodies.
Confocal microscopy of live human islets exposed to infectious viruses revealed a bright co-localisation of virus particles with studied cell surface molecules, suggesting that the studied cell surface molecules are capable of binding the virus (Fig. 3).

$P V R$ as a receptor for $P V-1 /$ Sabin. In primary human islets infected, in the absence or presence of PVR-specific antibody, with the Sabin strain of PV-1 we found that PV-1/Sabin replicated well, and that the replication took place in beta cells as shown by double immunofluorescence staining with virus- and insulinspecific antibodies (green and red respectively) (Fig. 4a, where the yellow-orange label corresponds to infected beta cells). The replication of PV-1/Sabin in primary human islets was blocked completely by the PVR-specific polyclonal antibody, as shown by double immunofluorescence staining (Fig. 4a), live-dead cell staining (Fig. 5d) and infectivity titration (Fig. 5a). The observed blocking effect was specific for this antibody, as poliovirus replication was not affected by the polyclonal antibody to the vitronectin receptor, $\alpha v \beta 3$ (Fig. 5a).

Effects of the polyclonal antibodies to PVR and integrin $\alpha v \beta 3$ on virus-induced beta-cell-specific function and destruction, as well as on stimulated insulin release and intracellular insulin content, are shown in Fig. 5b,c. Poliovirus-induced disturbance in beta cells was completely prevented by the PVR-specific antibody. 


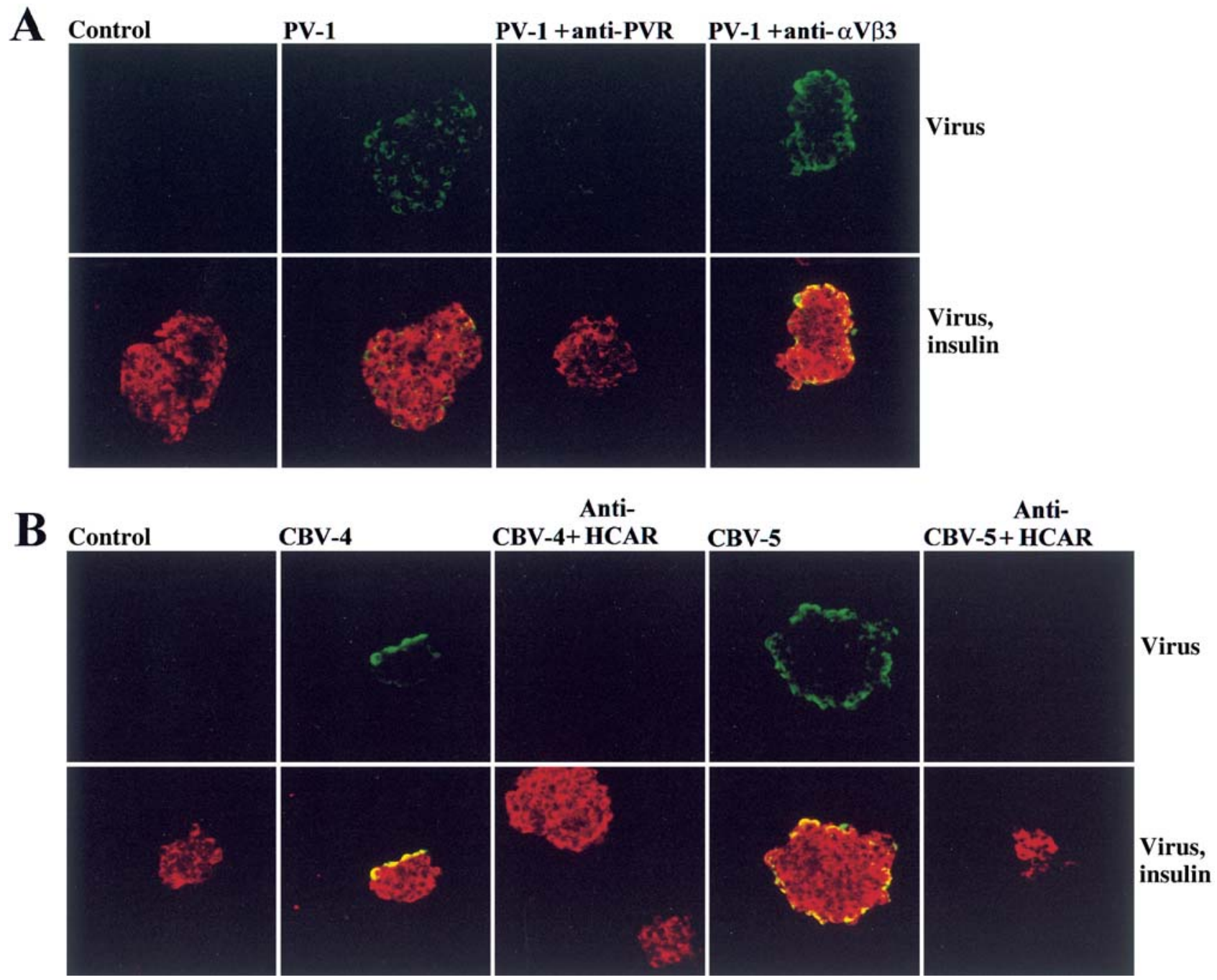

Fig. 4a, b. Anti-receptor antibodies protect human beta cells from infections caused by poliovirus type 1 (PV-1) and coxsackievirus B4 and 5 (CBV-4, CBV-5) as shown by double immunofluorescence staining with insulin and virus-specific antibodies. Samples of islets infected in the presence or absence of anti-poliovirus receptor PVR, dilution 1:100 (a) and antihuman coxsackivirus and adenovirus receptor (HCAR) at dilution 1:50 (b) were harvested one day after infection, cytocentrifuged on glass slides, fixed with cold methanol and doublestained with enterovirus-specific rabbit antiserum and insulinspecific sheep antiserum. Visualisation was achieved by staining with fluorescein isothiocyanate anti-rabbit conjugate (green: virus antigen) and Red-X-anti-sheep conjugate (red: insulin). Infected beta cells are yellow-orange

HCAR as a receptor for coxsackievirus $B 4$ and 5. In control human islets not pretreated with the HCAR antibody the infections of both coxsackieviruses progressed well. Virus-induced beta-cell-specific destruction was clearly evident in experiments where stimulated insulin release or intracellular insulin content per cellular DNA were assayed (Fig. 6b,c). In the case of both viruses, the HCAR-specific monoclonal antibody protected islets from virus-induced cellular death and beta-cell-specific destruction (Fig. 6b,c). Even 14 days after infection the islets were still alive when RmcB was present (Fig. 6d). Likewise, immunofluorescence staining for infected islets did not show any virus-positive cells in cultures inoculated in the presence of HCAR antibody (Fig. 4b). The HCAR antibody inhibited virus replication in islets infected with CBV-4 (Fig. 6a). In contrast, a clear progeny virus production was seen in cultures infected with $\mathrm{CBV}-5$ even in the presence of the HCAR antibody (Fig. 6a).

Integrin $\alpha v \beta 3$ as a receptor for CAV-9 but also for $E V-9$ and HPEV-1. In primary human islets infected with CAV-9 and HPEV-1 the polyclonal antibody to integrin $\alpha \mathrm{v} \beta 3$ prevented the destruction of beta cells at 2 weeks after infection (Fig. 7). The protective effect of the antibody was also seen in live/dead cell staining of islets, as shown below for CAV-9.

Studies on the protective effect of the polyclonal integrin $\alpha v \beta 3$ antibody were extended to other RGDcontaining strains of viruses, including the laboratory strain of EV-9/Barty and a clinical isolate of EV-9 / DM. PV-1/Sabin was used as a negative control. No 

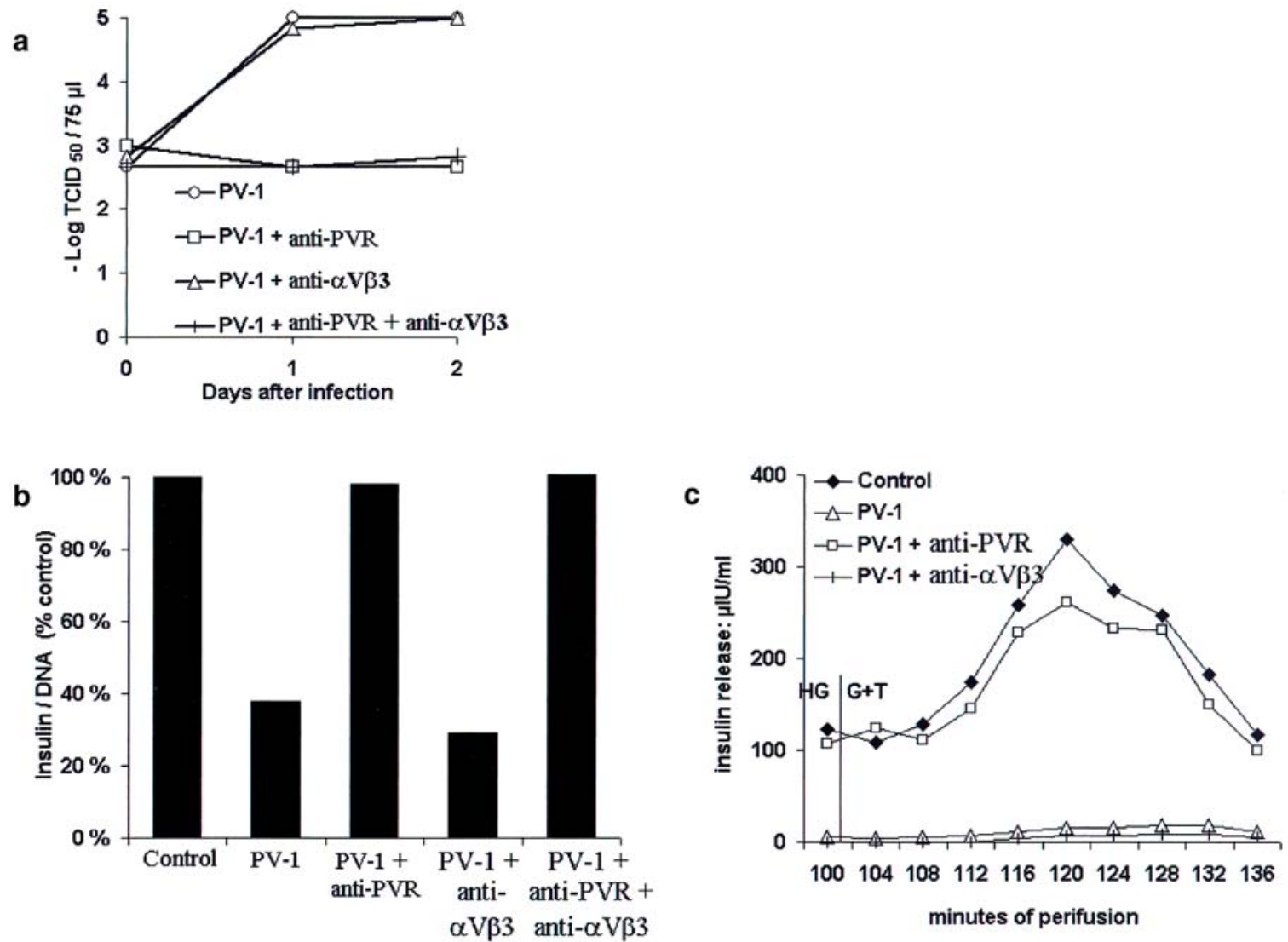

d

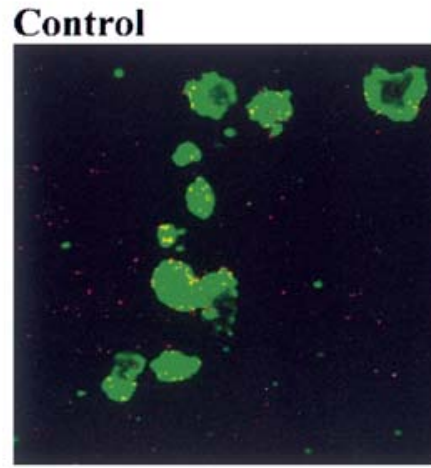

PV-1

PV-1 + anti-PVR
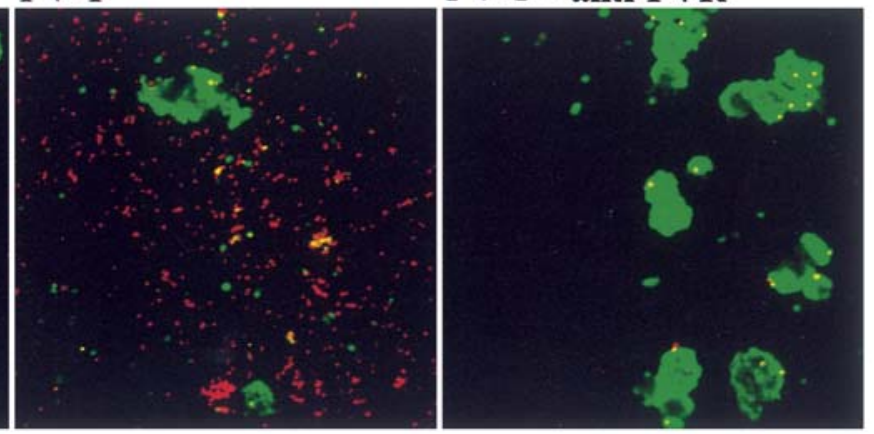

Fig. 5a-d. Poliovirus receptor-specific antibody inhibits replication of poliovirus type 1 (PV-1) and virus-induced beta cell consequences in primary human islets. Parallel aliquots of islets were incubated with the antibody (anti-poliovirus receptor PVR, anti- $\alpha v \beta 3$ was used as a negative control; dilution of 1:100) or the diluent and then infected with PV-1 at an apparent high multiplicity. Samples taken at 0,1 and 2 days after infection were assayed for total infectivity (a), at one week after infection for intracellular insulin content expressed per cellular DNA (b), for stimulated insulin release (c) and for cell viability (d). Results $(\mathbf{b}, \mathbf{c})$ are expressed as the relative change from the uninfected control. Live cells (d) are stained green by calcein due to their esterase activity, whereas red fluorescence was induced in the nuclei of dead cells by ethidium homodimer-1. Results obtained by several different methods from one complete experiment are shown. The blocking effect of the anti-receptor antibody was also evident in other islet cell preparations as shown by double-immunofluorescence staining with insulin and virus-specific antisera and live/dead-cell stainings signs of progeny virus were found in the presence of the antibody in cultures infected with EV-9/Barty, EV9/DM or the prototype strain of CAV-9/Griggs (Fig. 8). In contrast, progeny virus production of PV-1 / Sabin was not affected by the antibody (Fig. 8).

The protective effect of the antibody on beta-cellspecific destruction was shown by determining intracellular insulin content/DNA. All islets infected with CAV-9 or EV-9 were protected by the antibody. Likewise, results from live/dead-cell staining of cultures infected with tested non-polio enteroviruses showed the clear protective effect of the polyclonal antibody (Fig. 8).

The prototype strain of EV-9 Hill was also included in the study because according to our previous results this virus, although not having the RGD motif, is capable of using integrin $\alpha v \beta 3$ in its entry process at 
a

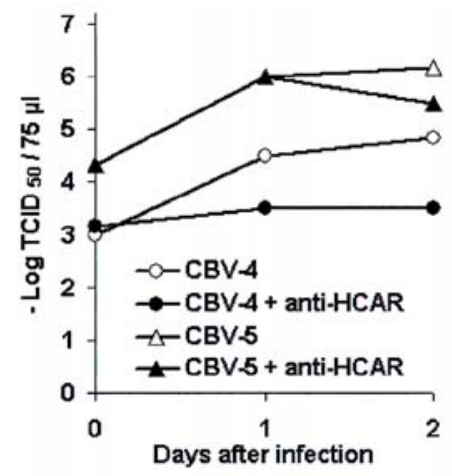

b

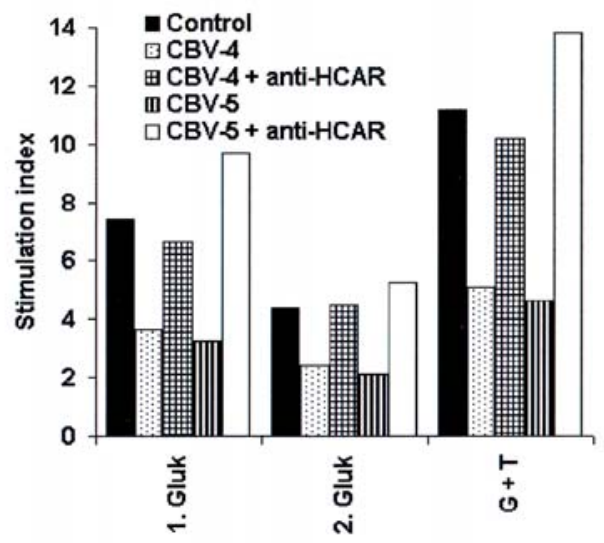

c

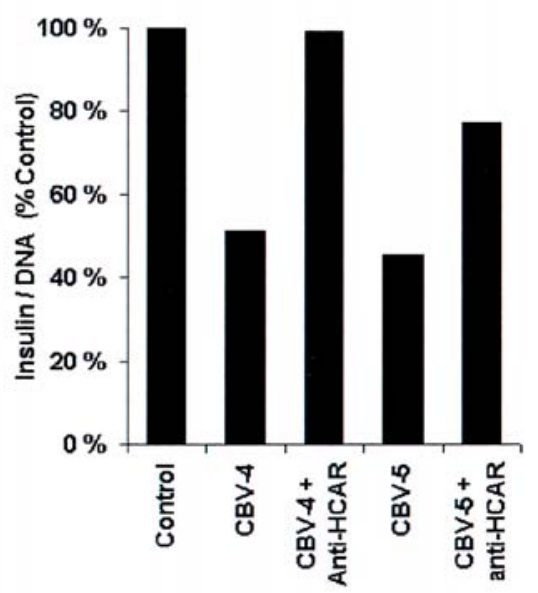

d

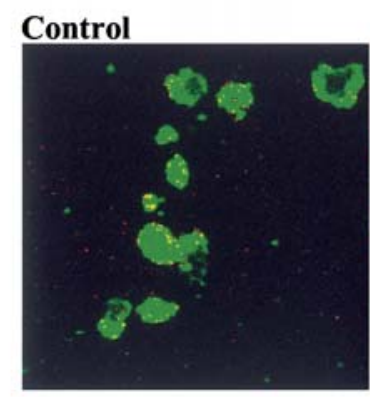

CBV-4

CBV-5
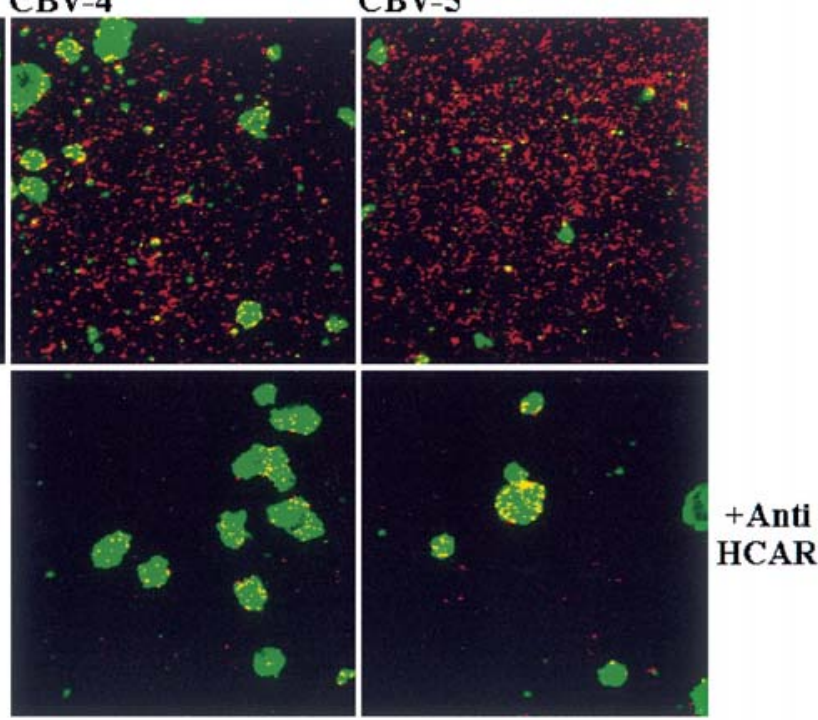

Fig. 6a-d. Human coxsackievirus (HCAR)-specific antibody inhibits replication of coxsackievirus B4 and 5 (CBV-4 and -5) and virus-induced beta cell-specific consequences in primary human islets. Parallel aliquots of islets were incubated with HCAR-specific antibody (dilution 1:100) or the diluent and then infected with CBV-4 or CBV-5 at an apparent high multiplicity. Samples taken at 0,1 and 2 days after infection were assayed for total infectivity (a), at one week after infection for stimulated insulin release (b) and for intracellular insulin content per cellular DNA (c), and at two weeks after infection for cell viability (d). Results $(\mathbf{b}, \mathbf{c})$ are expressed as the relative change from the uninfected control. Live cells (d) are stained green by calcein due to their esterase activity, whereas red fluorescence was induced in the nuclei of dead cells by ethidium homodimer-1. Results obtained by several different methods from one complete experiment are shown. The blocking effect of the anti-receptor antibody was also evident in other islet cell preparations as shown by double-immunofluorescence staining with insulin and virus-specific antisera and live/dead-cell stainings 


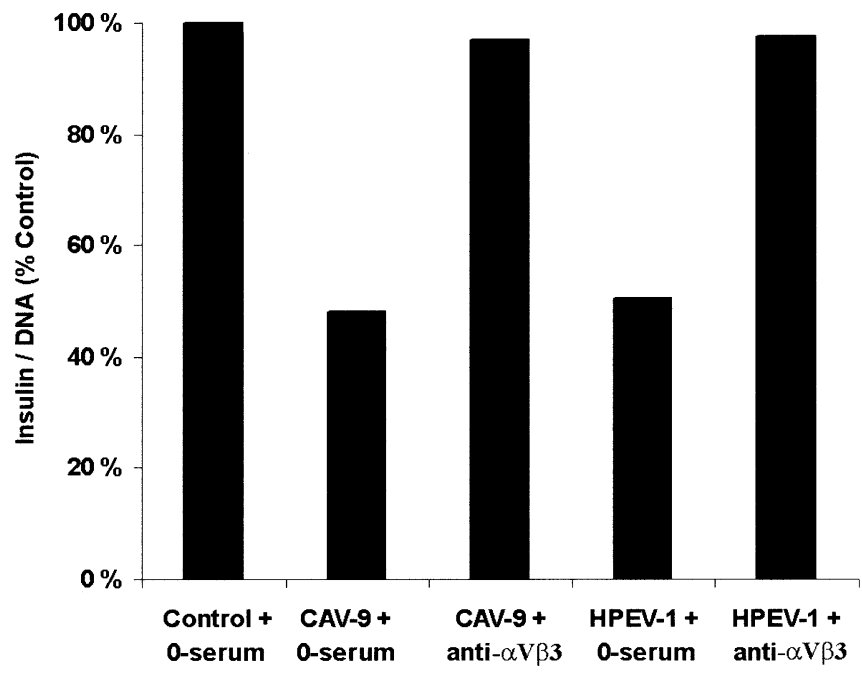

Fig. 7. Integrin $\alpha v \beta 3$-specific antibody protects islets from infections caused by coxsackievirus A9 (CAV-9) and human parechovirus 1(HPEV-1). Parallel aliquots of islets were incubated with $\alpha v \beta 3$-specific antibody (dilution 1:300) or the diluent and then infected with CAV-9 or HPEV-1 at an apparent high multiplicity. Samples taken at 2 weeks after infection were assayed for intracellular insulin per cellular DNA. The results are expressed as the relative change from the uninfected control

least in an established cell line of green monkey kidney [21]. However, replication of this virus in human islets, as well as virus-induced cellular death, was prevented by the polyclonal antibody to integrin $\alpha v \beta 3$ (Fig. 9).

\section{Discussion}

We have identified the cellular compartments infected by enteroviruses in the human pancreas. Our in situ hybridisation studies on pancreases of Type 1 diabetic patients showed enteroviral-positive cells exclusively in islets. This observation was very specific as no reactivity was seen in exocrine cells. Likewise, the islet-cell tropism of enteroviruses was clearly evident in pancreases of newborn infants dying of fulminant coxsackievirus infections as shown here by in situ hybridisation and previously by means of immunohistochemistry [48]. In our study enteroviral RNA was found in numerous pancreatic islets and in some duct cells but not in exocrine cells. This finding is in direct contrast with experimental infections in mice where enteroviruses had a propensity to the exocrine compartment. Thus localisation studies on mouse pancreases have identified virus in acinar cells but not in islets [41, 42, 43, 44, 45, 46, 47, 57]. In spite of almost complete destruction of the infected exocrine pancreas, the islets, ducts and connective tissue were selectively spared in mice infected with coxsackievirus B [42, 44, 46, 47, 58]. Our observations demonstrate an important species difference in the cell type specificity of pancreatic enterovirus infection.

Human diabetic pancreases from adults have been studied for viral infections, but no evidence of enterovirus infections was found $[48,59,60]$. In our study, too, most diabetic pancreases remained negative. Enteroviral RNA was found in only 4 of 65 pancreases obtained at autopsies. The duration of diabetes in these deceased persons was not known, and evidence of concurrent or historical enterovirus infections was not available. However, in heart specimens no signs of enterovirus myocarditis were seen. In contrast, several studies based on RT-PCR have shown the presence of enteroviral RNA in sera, blood cells or stools of people with recent onset Type 1 diabetes [9, 13, 14, 15].

Enteroviruses initiate infections in pancreatic as well as in all other target cells by attaching to cell surface receptor molecules, which are considered to play a key role in tissue tropism and hence in the generation of the spectrum of clinical symptoms. We showed that two cell surface proteins (PVR and integrin $\alpha v \beta 3$ ), both of which act as enterovirus receptors in established cell lines, are also expressed in primary human islets and especially in beta cells. Recently, expression of integrin subunits including $\alpha \mathrm{v}$ and $\beta 3$ in purified human beta cells was shown by semi-quantitative RT-PCR [61]. In contrast, no evidence was found for expression of DAF, which acts as a receptor for several of the islet cell replicating EVs in established cell lines, although different highly reactive DAF-specific monoclonal antibodies [51] were used. The absence of DAF was a surprise, as this glycosyl phosphatidylinositol-anchored protein, which is normally involved in regulating complement activity, is widely expressed in different tissues. It dissociates and prevents the assembly of C3/C5 convertases in the classic and alternate pathways of the complement system [62].

Antibodies to PVR, HCAR and integrin $\alpha \mathrm{v} \beta 3$ protected islets and beta cells from virus-induced adverse effects. In most cases the antibody also inhibited virus replication. Poliovirus infection and virus-induced effects on beta cells were completely blocked by PVRspecific polyclonal antiserum. Likewise, monoclonal antibody to HCAR prevented infection of CBV-4 and its consequences. Altogether, these results suggest that PVR and HCAR play key roles in infections caused in primary human islets by PV-1 and CBV-4 respectively. One previous study has suggested that HCAR plays a role in CBV infections of human islets [40]. However, the expression of HCAR in human beta cells is intriguing since practically no evidence of expression of the corresponding mouse protein was found in islets of murine pancreas [63]. PVR, a member of the immunoglobulin superfamily also thought to work as a receptor for vitronectin [64], is the only receptor known for three serotypes of poliovirus [17]. 

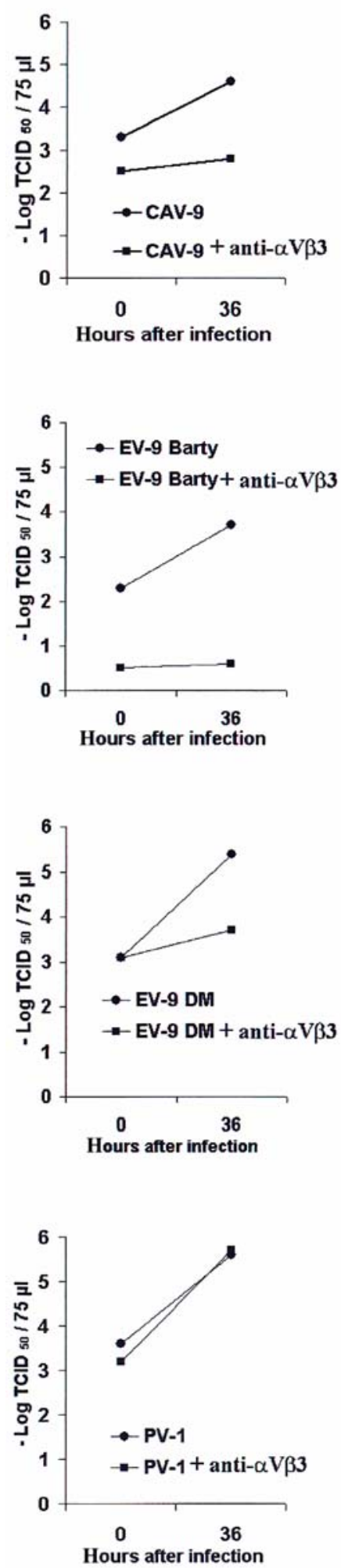

b
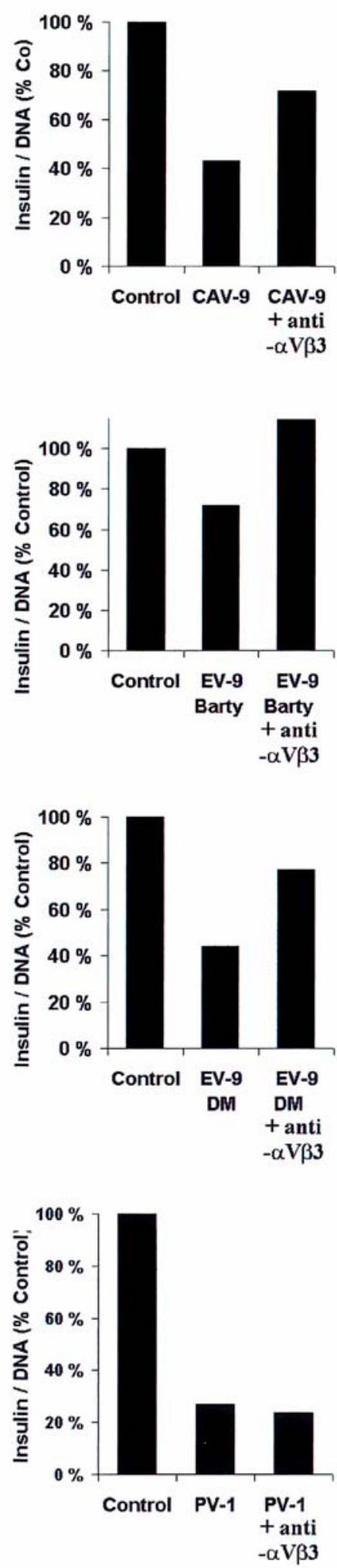

C

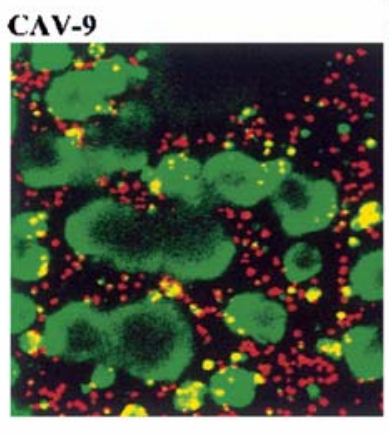

C.AV-9 + anti- $\alpha \mathrm{V} \beta 3$

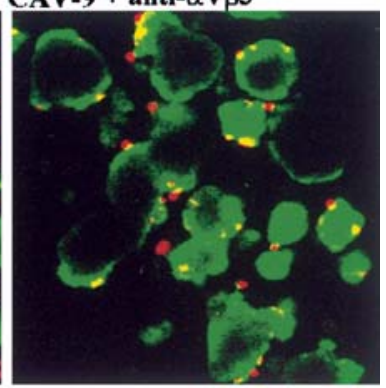

EV-9 Barty

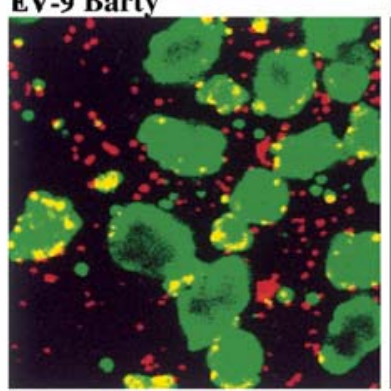

EV-9 DM

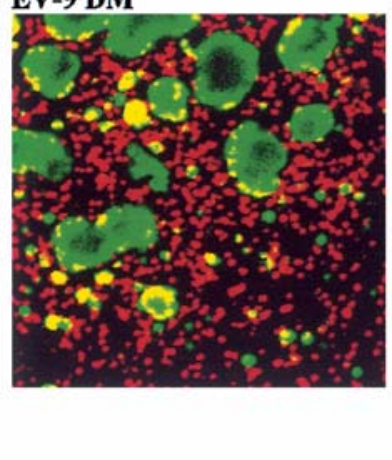

EV-9 Barty + anti- $\alpha$ V $\beta 3$

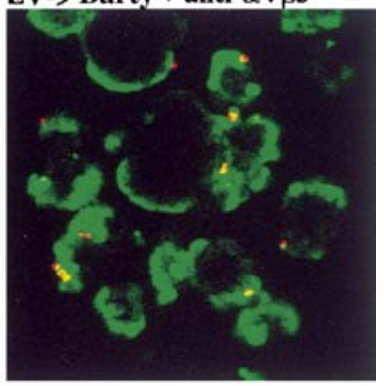

EV-9 DM+ anti- $\alpha$ Vß3

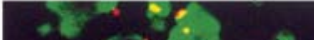

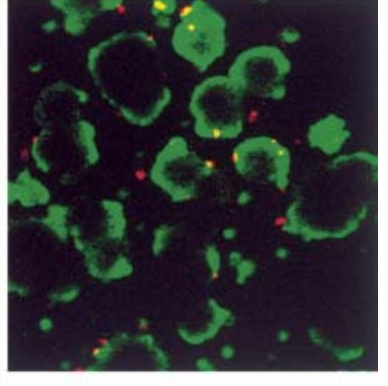

Fig. 8a-c. Integrin $\alpha v \beta 3$-specific antibody protects human islets from infections of enteroviruses containing arginine-glycine-aspartic acid. Parallel aliquots of islets were incubated with $\alpha v \beta 3$-specific antibody (dilution 1:50) or the diluent and then infected, with apparent high multiplicity, with echovirus 9/Barty (EV-9 Barty), echovirus 9/DM (EV-9 DM) or coxsackie A virus (CAV-9). Poliovirus 1 (PV-1) was used as a negative control. Samples taken 0 and $36 \mathrm{~h}$ after infection were assayed

for total infectivity (a) and at one week after infection for intracellular insulin content per cellular DNA (b) and cell viability (c). Results obtained by several different methods from one complete experiment are shown. The blocking effect of the anti-receptor antibody was also evident in other islet cell preparations as shown by double-immunofluorescence staining with insulin and virus-specific antisera and live/dead-cell stainings 
a

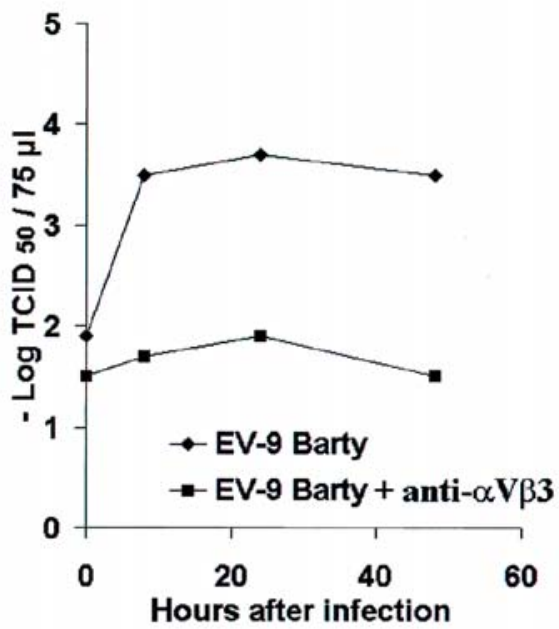

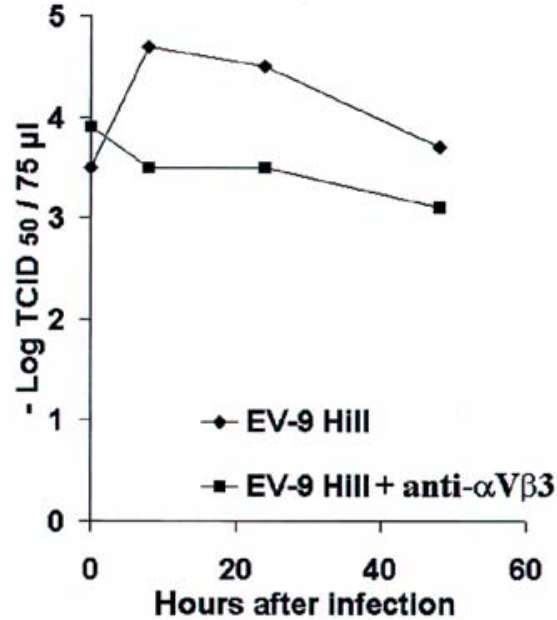

EV-9 IJill

\section{b Control}

EV-9 Barty
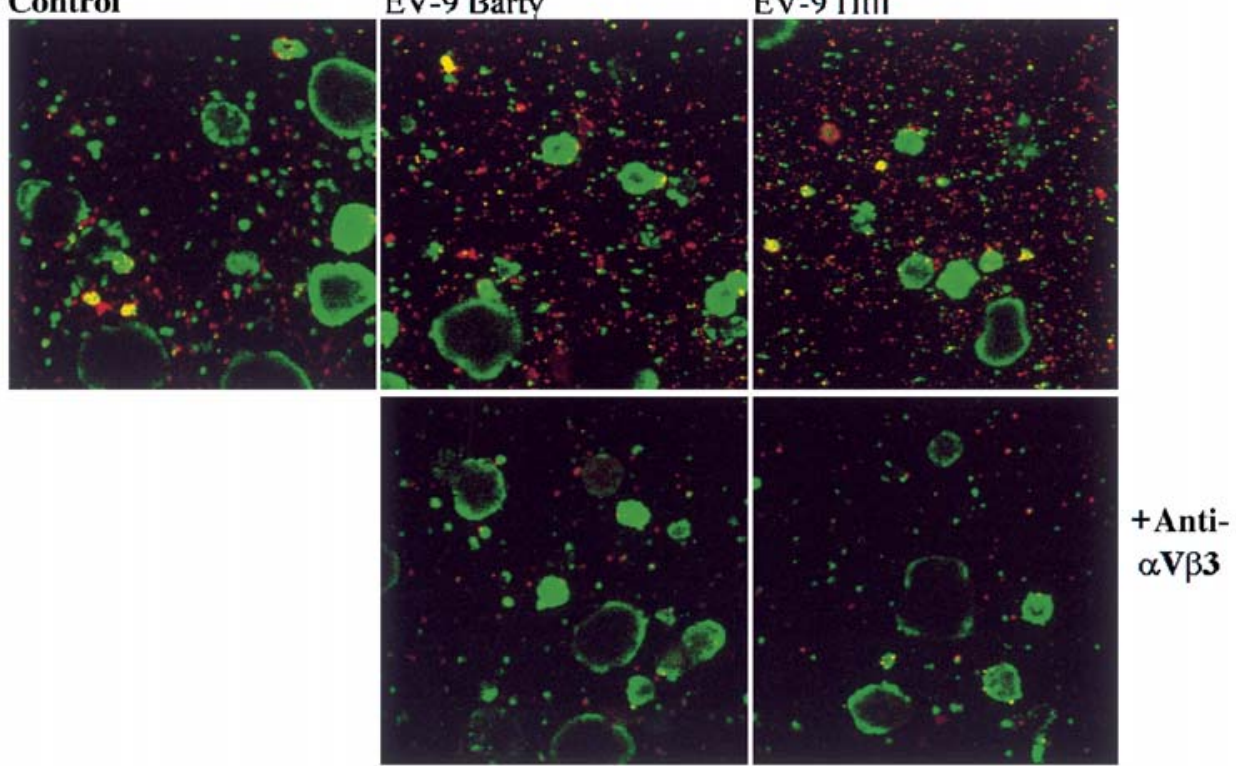

Fig. 9a, b. Integrin $\alpha v \beta 3$-specific antibody protects human islets from infection of echovirus 9/Hill (EV-9 Hill). Parallel aliquots of islets were incubated with $\alpha v \beta 3$-specific antibody (dilution 1:50) or the diluent and then infected, with apparent high multiplicity, with prototype strains of EV-9 Hill and echovirus 9 Barty (EV-9 Barty). Samples taken at different intervals were assayed for total infectivity (a), and at one week after infection for cell viability (b) by using a live/dead-cell assay kit. Results obtained by several different methods from one complete experiment are shown. The blocking effect of the antireceptor antibody was also evident in other islet-cell preparations as shown by double-immunofluorescence staining with insulin and virus-specific antisera and live/dead-cell stainings

On the other hand, islets infected with CBV-5 showed virus replication in the presence of HCAR antibody. This was a surprise because in the same experiment the antibody protected infected islets from virusinduced cellular death and beta-cell-specific defects. It is possible that even in the presence of the antibody, other non-insulin-producing islet cells are infected with CBV-5 in a less cytolytic way. For coxsackie B viruses, two different receptors, HCAR and DAF, have been identified in established cell lines, and especially serotypes $1,3,5$ are known to use either or both as receptors $[24,25,27,52,65]$. An important role of HCAR in the development of coxsackievirus diseases has been suggested in recent studies on clinical virus strains characterised after only one passage through primary green monkey kidney cells $[27,65]$.

In contrast to HCAR, DAF was not expressed in primary human islets and therefore this receptor cannot serve as an alternate receptor for CBVs in islets. In our studies no attempts were made to identify cell surface molecules used by other EVs in primary human islets and beta cells. Recently, a DAF-independent entry process through heparan sulfate has been characterised for some EVs in established cell lines $[30,66]$. This interaction could be of relevance in vivo as viruses showing this phenotype have been found among clinical low-passage isolates of EVs [67]. 
Integrin $\alpha v \beta 3$, also known as the vitronectin receptor, is used as a receptor for CAV-9 in several established cell lines $[19,68]$ as well as in primary human islets as shown here. Virus replication and virusinduced beta-cell-specific destruction were prevented by the anti-receptor polyclonal antibody. Moreover, in primary human beta cells this receptor was used by two other RGD-containing viruses, a laboratory strain of EV-9/Barty and HPEV-1, as beta-cell-specific destruction was inhibited by the same antibody. Interestingly, EV-9 strain Hill, the prototype that does not have the RGD-motif, was found to use the same vitronectin receptor in primary human islets. The receptor footprint on the EV-9 virion is not known. The vitronectin receptor, however, is well known for RGDindependent interactions with the natural ligand, vitronectin, and with some microbes [69]. Altogether, the results obtained with the vitronectin receptor-specific antibody show that this receptor works as a receptor for enteroviruses and HPEV-1 in primary human islets. Similar results have been reported in established cell lines [19, 20, 21, 70, 71].

Receptor usage by clinical strains is not strictly determined by the serotype. Variants with altered receptor specificity can arise during infection in humans. We studied the receptor specificity in primary human islets of a clinical strain, EV-9/DM, which had been isolated from a diabetic patient. This virus strain was more destructive in human islets than the corresponding prototype strains, as has been shown in comparative studies of different EV-9 strains and their tropism for pancreatic cells [21]. In the case of EV-9/DM the vitronectin receptor was responsible for beta-cell-specific destruction and virus replication in islets. Under some conditions, a virus can change receptor specificity and use another molecule as a receptor to mediate entry into the host cell. Differences in receptor specificity are found even among prototype strains passaged in various established cell lines [72]. The adaptation of a virus, allowing it to replicate in secondary target tissues, could extend the cell tropism of that virus, also affecting organ-specific symptoms of enterovirus infections [31]. The adaptation of CBV-2 to primary human islets did not change receptor specificity.

In conclusion, we have shown islet-cell tropism of enteroviruses in human pancreases in vivo. Enteroviral genomes were found in islets, but not in exocrine cells of the deceased newborn infants studied, as well as in Type 1 diabetic patients. These findings suggest that enteroviruses play a part in the development of Type 1 diabetes and that this part is based on direct action by enteroviruses on beta cells. We showed that the cell surface molecules, PVR, HCAR and integrin $\alpha v \beta 3$, which act as enterovirus receptors in established cell lines, are expressed in primary human islets and specifically in beta cells, and that these receptors are responsible for virus infections resulting in destruction of beta cells. It is possible, however, that other cell surface molecules contribute to infections in non-beta cells. In contrast, the cell surface molecule DAF was not expressed on islet cells, suggesting that another molecule acts as a receptor for several serotypes of EVs.

Acknowledgements. The authors wish to thank Dr A.K. Foulis (Glasgow, Scotland) for providing the pancreases from newborn infants with enterovirus infection and from some patients with Type 1 diabetes, Dr J. Galama (Nijmegen, The Netherlands) for the clinical strain DM of echovirus 9, M. Eskelinen for skillful technical assistance, and staff of the beta cell Transplant Laboratory, Brussels, Belgium and Uppsala University Hospital, Uppsala, Sweden for the preparation of human islet cells (coordinated in Brussels by Professor D. Pipeleers and in Uppsala by Professor O. Korsgren). This study was supported by the Finnish Diabetes Research Foundation and a partnership grant from the Academy of Finland, the Sigrid Juselius Foundation and The Juvenile Diabetes Research Foundation International (to M. Roivainen and T. Otonkoski). K. Klingel and R. Kandolf were supported by a grant from the Fortune program of the University Hospital of Tübingen (No. 951-0-0) and A.M. Lindberg by a grant from The Knowledge Foundation, Sweden.

\section{References}

1. Yoon JW, Austin M, Onodera T, Notkins AL (1979) Isolation of a virus from the pancreas of a child with diabetic ketoacidosis. N Engl J Med 300:1173-1179

2. Yoon JW (1990) The role of viruses and environmental factors in the induction of diabetes. Curr Top Microbiol Immunol 164:95-123

3. King ML, Shaikh A, Bidwell D, Voller A, Banatvala JE (1983) Coxsackie-B-virus-specific IgM responses in children with insulin- dependent (juvenile-onset; type I) diabetes mellitus. Lancet 1:1397-1399

4. Banatvala JE, Bryant J, Schernthaner G et al. (1985) Coxsackie $\mathrm{B}$, mumps, rubella, and cytomegalovirus specific IgM responses in patients with juvenile-onset insulin-dependent diabetes mellitus in Britain, Austria, and Australia. Lancet 1:1409-1412

5. Frisk G, Nilsson E, Tuvemo T, Friman G, Diderholm H (1992) The possible role of Coxsackie A and echo viruses in the pathogenesis of type I diabetes mellitus studied by IgM analysis. J Infect 24:13-22

6. Helfand RF, Gary HE Jr, Freeman CY, Anderson LJ, Pallansch MA (1995) Serologic evidence of an association between enteroviruses and the onset of type 1 diabetes mellitus. Pittsburgh Diabetes Research Group. J Infect Dis 172:1206-1211

7. Dahlquist GG, Ivarsson S, Lindberg B, Forsgren M (1995) Maternal enteroviral infection during pregnancy as a risk factor for childhood IDDM: A population-based case-control study. Diabetes 44:408-413

8. Hyoty H, Hiltunen M, Knip M et al. (1995) A prospective study of the role of coxsackie B and other enterovirus infections in the pathogenesis of IDDM. Childhood Diabetes in Finland (DiMe) Study Group. Diabetes 44:652-657

9. Clements GB, Galbraith DN, Taylor KW (1995) Coxsackie $B$ virus infection and onset of childhood diabetes. Lancet 346:221-223

10. Hiltunen M, Hyoty H, Knip M et al. (1997) Islet cell antibody seroconversion in children is temporally associated 
with enterovirus infections. Childhood Diabetes in Finland (DiMe) Study Group. J Infect Dis 175:554-560

11. Andreoletti L, Hober D, Hober-Vandenberghe $C$ et al. (1998) Coxsackie B virus infection and beta cell autoantibodies in newly diagnosed IDDM adult patients. Clin Diagn Virol 9:125-133

12. Lonnrot M, Salminen K, Knip M et al. (2000) Enterovirus RNA in serum is a risk factor for beta-cell autoimmunity and clinical type 1 diabetes: a prospective study. Childhood Diabetes in Finland (DiMe) Study Group. J Med Virol 61:214-220

13. Chehadeh W, Weill J, Vantyghem MC et al. (2000) Increased level of interferon-alpha in blood of patients with insulin- dependent diabetes mellitus: relationship with coxsackievirus B infection. J Infect Dis 181:1929-1939

14. Yin H, Berg AK, Tuvemo T, Frisk G (2002) Enterovirus RNA is found in peripheral blood mononuclear cells in a majority of type 1 diabetic children at onset. Diabetes 51: 1964-1971

15. Craig ME, Howard NJ, Silink M, Rawlinson WD (2003) Reduced frequency of HLA DRB $1 * 03-\mathrm{DQB} 1 * 02$ in children with type 1 diabetes associated with enterovirus RNA. J Infect Dis 187:1562-1570

16. King AMQ, Brown F, Christian P, Hovi T, Hyypiä T, Knowles NJ, Lemon SM, Minor PD, Palmenberg AC, Skern T, Stanway G.(2000) Family Picornaviridae. In: Van Regenmortel MHV, Fauquet CM, Bishop DHL, Calisher CH, Carsten EB, Estes MK, Lemon SM, Maniloff J, Mayo MA, McGeoch DJ, Pringle CR, Wickner RB (eds) Virus taxonomy. Seventh Report of the International Committee for the Taxonomy of Viruses. Academic Press, New York San Diego, pp 657-678

17. Mendelsohn CL, Wimmer E, Racaniello VR (1989) Cellular receptor for poliovirus: molecular cloning, nucleotide sequence, and expression of a new member of the immunoglobulin superfamily. Cell 56:855-865

18. Shafren DR, Dorahy DJ, Ingham RA, Burns GF, Barry RD (1997) Coxsackievirus A21 binds to decay-accelerating factor but requires intercellular adhesion molecule 1 for cell entry. J Virol 71:4736-4743

19. Roivainen M, Piirainen L, Hovi T et al. (1994) Entry of coxsackievirus A9 into host cells: specific interactions with alpha $\mathrm{v}$ beta 3 integrin, the vitronectin receptor. Virology 203:357-365

20. Stanway G, Kalkkinen N, Roivainen M et al. (1994) Molecular and biological characteristics of echovirus 22, a representative of a new picornavirus group. J Virol 68: 8232-8238

21. Paananen A, Ylipaasto P, Rieder E, Hovi T, Galama J, Roivainen M (2003) Molecular and biological analysis of echovirus 9 strain isolated from a diabetic child. J Med Virol 69:529-537

22. Bergelson JM, Shepley MP, Chan BM, Hemler ME, Finberg RW (1992) Identification of the integrin VLA-2 as a receptor for echovirus 1 . Science 255:1718-1720

23. Marjomaki V, Pietiainen V, Matilainen H et al. (2002) Internalization of echovirus 1 in caveolae. J Virol 76:18561865

24. Bergelson JM, Chan M, Solomon KR, St John NF, Lin H, Finberg RW (1994) Decay-accelerating factor (CD55), a glycosylphosphatidylinositol-anchored complement regulatory protein, is a receptor for several echoviruses. Proc Natl Acad Sci USA 91:6245-6249

25. Shafren DR, Bates RC, Agrez MV, Herd RL, Burns GF, Barry RD (1995) Coxsackieviruses B1, B3, and B5 use decay accelerating factor as a receptor for cell attachment. J Virol 69:3873-3877
26. Bergelson JM, Cunningham JA, Droguett G et al. (1997) Isolation of a common receptor for Coxsackie B viruses and adenoviruses 2 and 5. Science 275:1320-1323

27. Bergelson JM, Modlin JF, Wieland-Alter W, Cunningham JA, Crowell RL, Finberg RW (1997) Clinical coxsackievirus $B$ isolates differ from laboratory strains in their interaction with two cell surface receptors. J Infect Dis 175: 697-700

28. Tomko RP, Xu R, Philipson L (1997) HCAR and MCAR: the human and mouse cellular receptors for subgroup $C$ adenoviruses and group B coxsackieviruses. Proc Natl Acad Sci USA 94:3352-3356

29. Bergelson JM, Mohanty JG, Crowell RL, St John NF, Lublin DM, Finberg RW (1995) Coxsackievirus B3 adapted to growth in RD cells binds to decay-accelerating factor (CD55). J Virol 69:1903-1906

30. Powell RM, Schmitt V, Ward T, Goodfellow I, Evans DJ, Almond JW (1998) Characterization of echoviruses that bind decay accelerating factor (CD55): evidence that some haemagglutinating strains use more than one cellular receptor. J Gen Virol 79:1707-1713

31. Schmidtke M, Selinka HC, Heim A et al. (2000) Attachment of coxsackievirus B3 variants to various cell lines: mapping of phenotypic differences to capsid protein VP1. Virology 275:77-88

32. Triantafilou K, Fradelizi D, Wilson K, Triantafilou M (2002) GRP78, a coreceptor for coxsackievirus A9, interacts with major histocompatibility complex class I molecules which mediate virus internalization. J Virol 76: 633-643

33. Roivainen M, Narvanen A, Korkolainen M, Huhtala ML, Hovi T (1991) Antigenic regions of poliovirus type 3/Sabin capsid proteins recognized by human sera in the peptide scanning technique. Virology 180:99-107

34. Roivainen M, Piirainen L, Hovi T (1996) Efficient RGDindependent entry process of coxsackievirus A9. Arch Virol 141:1909-1919

35. Roivainen M, Knip M, Hyoty H et al. (1998) Several different enterovirus serotypes can be associated with prediabetic autoimmune episodes and onset of overt IDDM. Childhood Diabetes in Finland (DiMe) Study Group. J Med Virol 56:74-78

36. Yoon JW, Onodera T, Jenson AB, Notkins AL (1978) Virus-induced diabetes mellitus. XL. Replication of coxsackievirus B3 in human pancreatic beta cell cultures. Diabetes 27:778-781

37. Roivainen M, Rasilainen S, Ylipaasto P et al. (2000) Mechanisms of coxsackievirus-induced damage to human pancreatic beta cells. J Clin Endocrinol Metab 85:432-440

38. Roivainen M, Ylipaasto P, Savolainen C, Galama J, Hovi T, Otonkoski T (2002) Functional impairment and killing of human beta cells by enteroviruses: the capacity is shared by a wide range of serotypes, but the extent is a characteristic of individual virus strains. Diabetologia 45:693702

39. Frisk G, Diderholm H (2000) Tissue culture of isolated human pancreatic islets infected with different strains of coxsackievirus B4: assessment of virus replication and effects on islet morphology and insulin release. Int J Exp Diabetes Res 1:165-175

40. Chehadeh W, Kerr-Conte J, Pattou F et al. (2000) Persistent infection of human pancreatic islets by coxsackievirus $\mathrm{B}$ is associated with alpha interferon synthesis in beta cells. J Virol 74:10153-10164

41. Ross ME, Hayashi K, Notkins AL (1974) Virus-induced pancreatic disease: alterations in concentration of glucose and amylase in blood. J Infect Dis 129:669-676 
42. Szopa TM, Dronfield DM, Ward T, Taylor KW (1989) In vivo infection of mice with Coxsackie B4 virus induces long-term functional changes in pancreatic islets with minimal alteration in blood glucose. Diabet Med 6:314-319

43. Vuorinen T, Nikolakaros G, Simell O, Hyypia T, Vainionpaa R (1992) Mumps and Coxsackie B3 virus infection of human fetal pancreatic islet-like cell clusters. Pancreas 7:460-464

44. See DM, Tilles JG (1995) Pathogenesis of virus-induced diabetes in mice. J Infect Dis 171:1131-1138

45. Arola A, Kalimo H, Ruuskanen O, Hyypia T (1995) Experimental myocarditis induced by two different coxsackievirus B3 variants: aspects of pathogenesis and comparison of diagnostic methods. J Med Virol 47:251-259

46. Klingel K, Stephan S, Sauter M et al. (1996) Pathogenesis of murine enterovirus myocarditis: virus dissemination and immune cell targets. J Virol 70:8888-8895

47. Ramsingh AI, Chapman N, Tracy S (1997) Coxsackieviruses and diabetes. Bioessays 19:793-800

48. Foulis AK, Farquharson MA, Cameron SO, McGill M, Schonke H, Kandolf R (1990) A search for the presence of the enteroviral capsid protein VP1 in pancreases of patients with Type 1 insulin-dependent diabetes and pancreases and hearts of infants who died of coxsackieviral myocarditis. Diabetologia 33:290-298

49. Klingel K, Hohenadl C, Canu A et al. (1992) Ongoing enterovirus-induced myocarditis is associated with persistent heart muscle infection: quantitative analysis of virus replication, tissue damage, and inflammation. Proc Natl Acad Sci USA 89:314-318

50. Vreugdenhil GR, Schloot NC, Hoorens A et al. (2000) Acute onset of type I diabetes mellitus after severe echovirus 9 infection: putative pathogenic pathways. Clin Infect Dis 31:1025-1031

51. Kinoshita T, Medof ME, Silber R, Nussenzweig V (1985) Distribution of decay-accelerating factor in the peripheral blood of normal individuals and patients with paroxysmal nocturnal hemoglobinuria. J Exp Med 162:75-92

52. Hsu KH, Lonberg-Holm K, Alstein B, Crowell RL (1988) A monoclonal antibody specific for the cellular receptor for the group B coxsackieviruses. J Virol 62:1647-1652

53. Hovi T, Roivainen M (1993) Peptide antisera targeted to a conserved sequence in poliovirus capsid VP1 cross-react widely with members of the genus Enterovirus. J Clin Microbiol 31:1083-1087

54. Hinegardner RT (1971) An improved fluorometric assay for DNA. Anal Biochem 39:197-201

55. Otonkoski T, Beattie GM, Mally MI, Ricordi C, Hayek A (1993) Nicotinamide is a potent inducer of endocrine differentiation in cultured human fetal pancreatic cells. J Clin Invest 92:1459-1466

56. Otonkoski T, Hayek A (1995) Constitution of a biphasic insulin response to glucose in human fetal pancreatic betacells with glucagon-like peptide 1. J Clin Endocrinol Metab 80:3779-3783

57. Vella C, Brown CL, McCarthy DA (1992) Coxsackievirus B4 infection of the mouse pancreas: acute and persistent infection. J Gen Virol 73:1387-1394
58. Flodstrom M, Maday A, Balakrishna D, Cleary MM, Yoshimura A, Sarvetnick N (2002) Target cell defense prevents the development of diabetes after viral infection. Nat Immunol 3:373-382

59. Foulis AK, McGill M, Farquharson MA, Hilton DA (1997) A search for evidence of viral infection in pancreases of newly diagnosed patients with IDDM. Diabetologia 40:5361

60. Buesa-Gomez J, de la Torre JC, Dyrberg T et al. (1994) Failure to detect genomic viral sequences in pancreatic tissues from two children with acute-onset diabetes mellitus. J Med Virol 42:193-197

61. Ris F, Hammar E, Bosco D et al. (2002) Impact of integrinmatrix matching and inhibition of apoptosis on the survival of purified human beta-cells in vitro. Diabetologia 45:841850

62. Lublin DM, Atkinson JP (1989) Decay-accelerating factor: biochemistry, molecular biology, and function. Annu Rev Immunol 7:35-58

63. Mena I, Fischer C, Gebhard JR, Perry CM, Harkins S, Whitton JL (2000) Coxsackievirus infection of the pancreas: evaluation of receptor expression, pathogenesis, and immunopathology. Virology 271:276-288

64. Lange R, Peng X, Wimmer E, Lipp M, Bernhardt G (2001) The poliovirus receptor CD155 mediates cell-to-matrix contacts by specifically binding to vitronectin. Virology 285:218-227

65. Martino TA, Petric M, Weingartl H et al. (2000) The coxsackie-adenovirus receptor (CAR) is used by reference strains and clinical isolates representing all six serotypes of coxsackievirus group B and by swine vesicular disease virus. Virology 271:99-108

66. Goodfellow IG, Sioofy AB, Powell RM, Evans DJ (2001) Echoviruses bind heparan sulfate at the cell surface. J Virol 75:4918-4921

67. Goodfellow IG, Powell RM, Ward T, Spiller OB, Almond JW, Evans DJ (2000) Echovirus infection of rhabdomyosarcoma cells is inhibited by antiserum to the complement control protein CD59. J Gen Virol 81:1393-1401

68. Berinstein A, Roivainen M, Hovi T, Mason PW, Baxt B (1995) Antibodies to the vitronectin receptor (integrin alpha $\mathrm{V}$ beta 3) inhibit binding and infection of foot-andmouth disease virus to cultured cells. J Virol 69:2664-2666

69. Gavrilovskaya IN, Shepley M, Shaw R, Ginsberg MH, Mackow ER (1998) beta3 Integrins mediate the cellular entry of hantaviruses that cause respiratory failure. Proc Natl Acad Sci USA 95:7074-7079

70. Roivainen M, Hyypia T, Piirainen L, Kalkkinen N, Stanway G, Hovi T (1991) RGD-dependent entry of coxsackievirus A9 into host cells and its bypass after cleavage of VP1 protein by intestinal proteases. J Virol 65:47354740

71. Joki-Korpela P, Marjomaki V, Krogerus C, Heino J, Hyypia T (2001) Entry of human parechovirus 1. J Virol 75:19581967

72. Reagan KJ, Goldberg B, Crowell RL (1984) Altered receptor specificity of coxsackievirus B3 after growth in rhabdomyosarcoma cells. J Virol 49:635-640 